\title{
Probiotic potentials of Mucuna beans flour fermented with Lactobacillus acidophilus
}

\author{
Ojokoh Anthony Okhonlaye* and Oyetayo Adedayo Michael \\ Department of Microbiology, Federal University of Technology, P.M.B. 704, Akure, Nigeria. \\ Email: tonyojokoh@yahoo.com
}

Received 18 August 2014; Received in revised form 24 January 2015; Accepted 27 January 2015

\begin{abstract}
Aims: The specific aim of this study is to investigate the probiotic potentials of mucuna beans flour fermented with Lactobacillus acidophilus.

Methodology and results: The L. acidophilus used was isolated from neonate faeces using the pour plate technique, thereafter, it was screened for growth and survival in the mucuna beans flour. Liquid fermentation method was adopted for fermentation of mucuna beans flour and at the end of $72 \mathrm{~h}$ fermentation at $37{ }^{\circ} \mathrm{C}$, the L. acidophilus showed appreciable growth $\left(90 \times 10^{5} \mathrm{CFU} / \mathrm{mL}\right)$. After storage for 14 days at refrigeration $\left(4 \pm 2{ }^{\circ} \mathrm{C}\right)$ and room temperature $(25 \pm$ $2{ }^{\circ} \mathrm{C}$ ), there was a considerable increase in the Lactobacillus found in the products stored at room temperature (183.67 \pm $3.28 \times 10^{5} \mathrm{CFU} / \mathrm{mL}$ ) compared to the one stored at refrigeration temperature $\left(94 \pm 2.33 \times 10^{5} \mathrm{CFU} / \mathrm{mL}\right)$. There was a steady increase in the total titratable acidity and temperature with concomitant reduction in the $\mathrm{pH}$ of samples during the fermentation period. The proximate analysis showed that there was an increase in the protein and moisture contents with decrease in carbohydrates, fats, fiber and ash contents of the fermented samples compared to the unfermented sample. Under varying $\mathrm{pH}$ range, $L$. acidophilus showed high growth and survival at $\mathrm{pH} 2$ to 3 . Supplementing the diet of albino rats infected with $E$. coli and Shigella with fermented products reduces significantly $(p \leq 0.05)$ the numbers of these pathogens and other enteric bacteria while the number of the Lactobacilli increased considerably. Furthermore, the body weight of the rats fed the fermented product was significantly $(p \leq 0.05)$ higher than the control group. Also, the haematological analysis showed that the rats infected with the pathogens and later fed the fermented mucuna beans flour recovered fully since their values are well within the permissible limit and are not significantly $(p \leq 0.05)$ different from the control group. In all, the rats fed the product fermented with $L$. acidophilus showed good recovery compared to the control.

Conclusion, significance and impact of study: The results of this investigation suggest that mucuna beans flour supports the growth and survival of $L$. acidophilus and exerts considerable probiotic effect on young mammals. Therefore, mucuna may be used as an ideal probiotic food.
\end{abstract}

Keywords: Probiotic, L. acidophilus, mucuna flour, fermentation

\section{INTRODUCTION}

Probiotics are live bacteria that may confer a health benefit on the host. The term has been expressed as substances secreted by one microorganism that stimulate another microorganism (Lilly and Stillwell, 1965). Again, the term was used to describe tissue extracts which stimulated microbial growth (Sperti, 1971). Presently, probiotics is described as "live microbial feed supplement which beneficially affects the host animal by improving its intestinal microbial balance" (Fuller, 1989). There are two important facts of probiotics: the viable nature of probiotics and the capacity to help with intestinal balance. In addition, the following properties and functions have been attributed to probiotics: they adhere to host epithelial tissue; they are acid resistant and bile tolerant; they are safe, non-pathogenic and non-carcinogenic; they cause improvement of the intestinal microflora; they have a cholesterol lowering, immuno-stimulating and allergy lowering effect; they are also known to synthesize and enhance the bioavailability of nutrients (Sanders, 2003).

Lactic acid bacteria ( $L A B$ ) and Bifidobacteria are the most common types of microbes used as probiotics, but certain yeasts and bacilli may also be used. Probiotics are commonly consumed as part of fermented foods with specially added active live cultures, such as in yogurt, soy yogurt, or as dietary supplements (Guarner and Scaafsma, 1998). Among a number of functional properties attributed to foods, probiotics take a centre stage. Vasiljevic and Shah (2008) reported that the World Health Organization (WHO) in 1994 deemed probiotics to be the next most important immune defense systems as a 
result of increasing antibiotic resistance of commonly prescribed antibiotics.

Mucuna pruriens (velvet beans, itching bean) is an underutilized legume species found predominantly in Asia, Africa, in parts of America (Gilbert, 2002). Mature seeds, seeds from unripe pods and young pods of itching bean, Mucuna pruriens are soaked and boiled/roasted and eaten as such or mixed with salt by the North-East Indian tribes, South Indian tribes (Ferriera et al., 2003). In Nigeria, Mucuna is cultivated in southern and middle belt states (Ani and Adiegwu, 2005). To make this less- known legume palatable, tribal people follow a special processing method of continuous boiling and draining for about eight times until the boiled water changes from black to milky white. Consumption of improperly boiled seeds of itching bean is known to cause increase in body temperature and skin eruptions (Janardhanan et al., 2003). However, it has been reported to possess several medicinal values among which are Seeds possess anabolic, androgenic, analgesic (pain-relieving), antiinflammatory, anti-Parkinson's, antispasmodic, antivenin, aphrodisiac, febrifuge (fever reducing), hormonal, hypocholesterolemic (cholesterol lowering), hypoglycemic, immunomodulator, nervine (nerve balancing), neurasthenic (nerve pain relieving), antilithic (kidney stones preventing or eliminating), antiparasitic, cough suppressant, blood cleanser, carminative (gas expelling), central nervous system stimulant, diuretic, hypotensive (blood pressure lowering), menstrual stimulant, uterine stimulant and vermifuge. Mucuna is widely distributed in south west Nigeria where it is underutilized, also most food that are presently used as probiotic vehicles are rather expensive for many Nigerians most of who live in poverty. The objective of this study is therefore to evaluate the probiotic potentials of mucuna beans flour fermented with Lactobacillus acidophilus.

\section{MATERIALS AND METHODS}

\section{Source of organisms}

Lactobacillus acidophillus used in this study was isolated from neonate stool. Enterotoxigenic strain of $E$. coli (0157:H7ATCC 25922) and Shigella dysenteriae (ATCC 72022) were obtained from the stock culture of Medical Microbiology Laboratory of University College Hospital, Ibadan.

\section{Source of mucuna bean grains}

The Mucuna beans (Mucuna priuriens) was collected fresh from the wild in the outskirt of Owo, Ondo State and was authenticated at the Department of Plant Sciences, Olabisi Onabanjo University, Ago-Iwoye before it was transferred to the laboratory for analysis.

\section{Source of experimental animals}

Forty (40) albino rats (Rattus norvegicus) aged 6 weeks were sourced from the Faculty of Veterinary Medicine,
University of Ibadan. They were housed in stainless steel cages under controlled conditions and placed on a basal diet purchased from Top feeds, Sapele, Delta State, Nigeria.

\section{Reagents/chemicals}

All reagents and chemicals were obtained from the Department of Microbiology, Federal University of Technology, Akure, Ondo State Nigeria. They include De Mann Rogosa and Sharpe Agar (Lab M, Lankershire, U. K.) for recovery and enumeration of Lactobacillus species, MacConkey Agar (Oxoid, U. K.) for enumeration of enteric bacteria, Eosine Methylene Blue Agar (Oxoid, U. K.) for enumeration of $E$. coli, Deoxycholate Citrate Agar (Oxoid, U. K.) for enumeration of Shigella species.

\section{Experimental design}

\section{Culturing and harvesting of Lactobacillus cells}

Overnight broth cultures of test isolates $L$. acidophilus were centrifuged at $10,000 \mathrm{rpm}$ for $15 \mathrm{~min}$. The pellets were rinsed out thrice with $10 \mathrm{~mL}$ phosphate buffer saline (PBS) into sterilized universal bottles and kept as stock cultures in the refrigerator at $4 \pm 2{ }^{\circ} \mathrm{C}$. The total viable cell in the stock solution was then determined using serial dilution and pour plate methods.

\section{Preparation of mucuna flour}

Seeds of Mucuna priurens were boiled in a pressure pot for 30 min to soften the seed and make the seed coats easily removable. Then, the peeled beans were boiled and the water changed three times to reduce the toxin content of the seed. Thereafter, the beans were rinsed in distilled water, dried and ground to powder to make the mucuna beans flour.

\section{Fermentation and storage}

The fermentation was carried out using the method Ojokoh and Daramola (2012). Mucuna beans flour was mixed with distilled water $(1: 3)$ in 3 fermentation jars labeled LA1, LA2 and X. (LA1 = jar inoculated with $L$. acidophilus and used for supplementing the rats feed, LA2 $=$ jar inoculated with $L$. acidophilus and used for storage) which were autoclaved at $121^{\circ} \mathrm{C}$ for $15 \mathrm{~min}$. Jars were allowed to cool after which each jar was inoculated with $10^{7} \mathrm{CFU} / \mathrm{mL}$ each of the test isolates $L$. acidophilus and $X$ was uninoculated serving as the control. After thorough mixing, the properly corked jars were incubated anaerobically at $37^{\circ} \mathrm{C}$ for $72 \mathrm{~h}$ for fermentation to take place. After, fermentation jars LA1, was stored at $4 \pm 2{ }^{\circ} \mathrm{C}$ while LA2 was stored at $25 \pm 2{ }^{\circ} \mathrm{C}$ (room temperature) for 14 days respectively. Viable counts of $L A B$ in the products were determined during the period of fermentation and after storage. 


\section{Microbial analysis}

Samples collected during the fermentation (at 0, 24, 48 and $72 \mathrm{~h}$ ) and storage (after 14 days at $4 \pm 2{ }^{\circ} \mathrm{C}$ and $25 \pm$ $2{ }^{\circ} \mathrm{C}$ respectively) were used for bacterial enumeration using serial dilution and pour plate method on De Mann Rogosa and Sharpe Agar. Plates were incubated anaerobically at $37^{\circ} \mathrm{C}$ for $48 \mathrm{~h}$ to determine the best $\mathrm{LAB}$ species in terms of growth and survival in mucuna beans flour.

\section{Physicochemical analyses}

\section{$\mathrm{pH}$ and total titrable acidity}

A mixture of $10 \mathrm{~g}$ of each fermented product was used for $\mathrm{pH}$ determination as described in AOAC (1995). Total titratable acidity (TTA) was determined by titrating $20 \mathrm{~mL}$ of the same sample against $0.1 \mathrm{M} \mathrm{NaOH}$.

\section{Proximate composition}

The moisture, crude fibre, fat, protein $(\mathrm{N} \times 6.25)$, ash and carbo-hydrate contents of both the fermented and unfermented samples were determined using the method of AOAC (1995).

\section{In vitro studies of gastrointestinal tolerance}

Isolate's tolerance to different acidic conditions was tested by centrifuging overnight culture of the test isolate for 10 $\mathrm{min}$ at $3000 \mathrm{rpm}$. The pellet was then resuspended in the same volume of saline solution $(9.8 \mathrm{~g}$ of $\mathrm{NaCl}$ in $1000 \mathrm{~mL}$ of distilled water). One milliliter of this dilution (pellet in saline solution) was plated for each of the isolates; this was done so as to estimate the number of viable cells that will be subjected to the acidic $\mathrm{pH}$. Sterile distilled water were measured into four labeled sterile beakers, these were adjusted to $\mathrm{pH} 2,3,4$ and 5, using phosphate buffer, $9 \mathrm{~mL}$ each of the acidified water were transferred into already labeled test tubes in triplicate for each $\mathrm{pH}$ level. Then, $1 \mathrm{~mL}$ of the resuspended pellet containing the isolates were inoculated into the appropriate test tubes, this was shaken and incubated at $37^{\circ} \mathrm{C}$ for $3 \mathrm{~h}$. After the three hours incubation, the appropriate dilutions was plated on De Mann Rogosa and Sharpe Agar and incubated anaerobically at $37^{\circ} \mathrm{C}$ for $48 \mathrm{~h}$. After subjecting the different isolates to different $\mathrm{pH}$ range, the resulting colonies after incubation were counted. The tolerance of the isolates to acidic $\mathrm{pH}$ was detected by comparing the number of $\mathrm{CFU} / \mathrm{mL}$ before exposure to the acidic $\mathrm{pH}$ with the values after subjection. Also, survival in bile was done by inoculating test isolates into broth containing $10 \%$ ox bile which was incubated overnight at $37^{\circ} \mathrm{C}$. Then, $1 \mathrm{~mL}$ of this culture was plated on MRS agar and incubated for $48 \mathrm{~h}$ at $37^{\circ} \mathrm{C}$, survival in bile is taken as growth on the plates.

\section{In vivo studies}

\section{Experimental animals}

Isolation and enumeration of the microbial flora in the G.I.T. of apparently healthy albino rats were carried out before the experimental animals were randomly assigned to 6 treatments $A, B, C, D, E$ and $F$ of 4 rats each. Treatments $A$ and $B$ were not infected, while $C$ and $E$ were infected with $E$. coli $\left(0.3 \mathrm{~mL}\right.$ of $10^{5} \mathrm{CFU} / \mathrm{mL}$ daily for 3 days) and $D$ and $F$ were infected with Shigella dysenteriae $\left(0.2 \mathrm{~mL}\right.$ of $10^{2} \mathrm{CFU} / \mathrm{mL}$ for 3 days). After a 4day post ingestion period was observed, diet of treatments $E$ and $F$ were supplemented with $10 \mathrm{~g}$ each of the fermented sample for 28 days. After feeding on the experimental diet for 4 weeks, all animals were fed the control (basal diet) for a further 14 days. Thereafter, total weight gain and fecal characteristics (color and texture), were observed while bacterial enumeration of fecal samples at $0,7,14,21,28,35,42$ and 49 days was also determined using conventional techniques. All animals were placed on a basal diet ad libitum.

\section{Haematolological parameter and internal organs measurement}

At the end of the study, all rats were fasted overnight and blood was collected from the common carotid artery into a heparinized tube for hematological studies. Complete blood count, red blood cell count, platelet count hemoglobin and packed cell volume were determined using an automatic counter (Sysmex K21, Tokyo, Japan). After the blood collection, internal organs including heart, lungs, liver and kidneys were weighed in triplicates.

\section{Statistical analysis}

All data were recorded in triplicate and unless otherwise indicated, results are expressed as means \pm SEM of three replicates. Data were subjected to one-way analysis of variance (ANOVA) using SPSS version 15.0. The Duncan's Multiple Range test was used to separate the means at the $5 \%$ level of probability

\section{RESULTS}

The tolerance of the L. acidophilus used in different $\mathrm{pH}$ conditions and bile are presented in Table 1 where the organism showed profuse growth at $\mathrm{pH} 4$ and moderate growth in $10 \%$ bile. The $\mathrm{pH}$, titratable acidity and temperature changes during the fermentation of mucuna beans flour is presented on Table 2 . There was significant $(p \leq 0.05)$ increase in the total titratable acidity from $0.31 \%$ to $2.22 \%$ for the fermented samples at the end of the fermentation period while there was significant decrease $(p \leq 0.05)$ in the $\mathrm{pH}$ of the samples from 6.77 to 3.07 after $72 \mathrm{~h}$ fermentation. 
Table 1: Lactobacillus growth after different treatment.

\begin{tabular}{lccccc}
\hline Factors & $\mathrm{pH} 2$ & $\mathrm{pH} \mathrm{3}$ & $\mathrm{pH} \mathrm{4}$ & $\mathrm{pH} \mathrm{5}$ & $10 \%$ bile \\
\hline Growth & + & ++ & +++ & ++ & ++ \\
\hline
\end{tabular}

+ , little growth; ++, moderate growth; +++, profuse growth

Table 2: Changes in physicochemical indices of the mucuna flour during fermentation (values are mean \pm S.E.M).

\begin{tabular}{lccc}
\hline $\begin{array}{l}\text { Time } \\
(\mathrm{h})\end{array}$ & Temperature & $\mathrm{pH}$ & TTA $(\%)$ \\
\hline 0 & $25.07 \pm 0.03^{\mathrm{a}}$ & $6.77 \pm 0.01^{\mathrm{c}}$ & $0.31 \pm 0.01^{\mathrm{a}}$ \\
24 & $26.23 \pm 0.20^{\mathrm{b}}$ & $5.11 \pm 0.02^{\mathrm{b}}$ & $1.58 \pm 0.02^{\mathrm{b}}$ \\
48 & $26.73 \pm 0.12^{\mathrm{b}}$ & $4.01 \pm 0.01^{\mathrm{b}}$ & $2.05 \pm 0.02^{\mathrm{b}}$ \\
72 & $27.73 \pm 0.12^{\mathrm{b}}$ & $3.07 \pm 0.03^{\mathrm{a}}$ & $2.22 \pm 0.01^{\mathrm{c}}$ \\
\hline
\end{tabular}

TTA, Total titratable acidity; LAM, mucuna flour fermented with $L$. acidophilus. Values with different superscripts in each column are significantly different.

The result of survival of the $L$. acidophilus is presented in Table 3 where the population increased with the time of fermentation. The Lactobacillus count increased from $69.67 \times 10^{5}$ to $90.00 \times 10^{5} \mathrm{CFU} / \mathrm{mL}$ in mucuna flour.

Table 3: Survival of the Lactobacillus species $\left(10^{5}\right.$ $\mathrm{CFU} / \mathrm{mL}$ ) in the fermenting $M$. pruriens flour (values are mean \pm S.E.M).

\begin{tabular}{ll}
\hline Time $(\mathrm{h})$ & L. acidophilus \\
\hline 0 & $69.67 \pm 0.88^{\mathrm{a}}$ \\
24 & $70.67 \pm 0.33^{\mathrm{a}}$ \\
48 & $77.67 \pm 0.67^{\mathrm{b}}$ \\
72 & $90.00 \pm 1.53^{\mathrm{c}}$ \\
\hline
\end{tabular}

At the end of the storage period, there was significant increase in the bacterial counts stored at room temperature compared to the ones stored at refrigeration temperature (Table 4).

Table 4: Lactobacillus count $\left(10^{5} \mathrm{CFU} / \mathrm{mL}\right)$ in the fermented mucuna beans flour after 14 days storage at different temperature (values are mean \pm S.E.M).

\begin{tabular}{lcc}
\hline Day & Fridge & Room temperature \\
\hline 0 & $90.00 \pm 1.53^{\mathrm{a}}$ & $90.57 \pm 1.53^{\mathrm{a}}$ \\
14 & $94.67 \pm 2.33^{\mathrm{a}}$ & $183.67 \pm 3.28^{\mathrm{b}}$ \\
\hline
\end{tabular}

Values with different superscripts on each row are significantly different.

The proximate composition of the raw and fermented mucuna flour is shown on Table 5 . There was significant increase in moisture and protein content in all the fermented samples while there was significant decrease in fat, fibre, ash and carbohydrate.

Table 5: Proximate composition of Mucuna pruriens fermented with $L$. acidophilus (values are mean \pm S.E.M).

\begin{tabular}{lcc}
\hline Parameter & RWM & LAM \\
\hline Moisture & $9.59 \pm 0.10^{\mathrm{a}}$ & $17.61 \pm 0.34^{\mathrm{b}}$ \\
Protein & $29.37 \pm 0.25^{\mathrm{a}}$ & $37.36 \pm 0.22^{\mathrm{b}}$ \\
Fat & $7.14 \pm 0.08^{\mathrm{b}}$ & $3.03 \pm 0.02^{\mathrm{a}}$ \\
Fibre & $6.54 \pm 0.08^{\mathrm{b}}$ & $3.29 \pm 0.06^{\mathrm{a}}$ \\
Ash & $4.35 \pm 0.13^{\mathrm{b}}$ & $3.59 \pm 0.02^{\mathrm{a}}$ \\
Carbohydrate & $51.92 \pm 0.62^{\mathrm{b}}$ & $44.79 \pm 0.52^{\mathrm{a}}$ \\
\hline
\end{tabular}

LAM, mucuna flour fermented with $L$. acidophilus; RWM, raw mucuna flour. Values with different superscripts in each column are significantly different.

Table 6: Fecal characteristics of rats fed with fermented mucuna flour.

\begin{tabular}{lcclllllc}
\hline Treatments & Day 0 & Day 7 & Day 14 & Day 21 & Day 28 & Day 35 & Day 49 & Remarks \\
\hline A & DB/FM & DB/FM & DB/FM & DB/FM & DB/FM & DB/FM & DB/FM & N D \\
B & LB/FM & LB/FM & LB/FM & LB/FM & LB/FM & LB/FM & DB/FM & N D \\
C & DB/FM & DB/WL & DB/WL & DB/WL & DB/WL & DB/WL & DB/WL & DD \\
D & DB/FM & DB/WLB & DB/WLB & DB/WLB & DB/WLB & DB/WLB & DB/WL & BDD \\
E & DB/FM & DB/WL & LB/WL & LB/WL & LB/SF & LB/FM & DB/FM & N D \\
F & DB/FM & DB/WLB & LB/WLB & LB/WL & LB/SF & LB/FM & DB/FM & N D \\
\hline
\end{tabular}

$\mathrm{DB}$, dark brown faeces; LB, light brown faeces; FM, formed moist faeces; WL, wet loose faeces; WLB, bloody diarrhear; SF, semi formed faeces. A, rats fed basal diet only; B, rats fed with fermented mucuna flour only; C, rats infected with $E$. coli without treatment; $D$, rats infected with Shigella without treatment; $E$, rats infected with $E$. coli and then fed with $L$. acidophilus fermented mucuna flour; $F$, rats infected with Shigella and then fed with $L$. acidophilus fermented mucuna flour.

The faecal characteristics of the rats during the in vivo feeding trials are presented on the Table 6. Rats infected with E. coli and Shigella (C, D) showed symptoms of diarrhea and bloody diarrhea respectively throughout the feeding period while those infected with $E$. coli and Shigella, and then fed experimental diet (E and $F$ ) showed diarrhea $(E)$ and bloody diarrhea $(F)$ during the first 21 days and 17 days respectively. However, the uninfected groups (A, B) did not show any sign of diarrhea throughout the experimental period.
Results of the microbial analysis of the faecal samples of the rats are shown in Figures 1 to 6 . At the end of the 52 days of feeding,, there was a significant increase $(p \leq$ 0.05 ) in the number of lactobacilli in groups fed with the experimental diet compared with the control groups (A, $\mathrm{B}, \mathrm{C}$ and $\mathrm{D}$ ), while the number of $E$. coli and Shigella as well as other Enterobacteria decreased $(p \leq 0.05)$ significantly. 


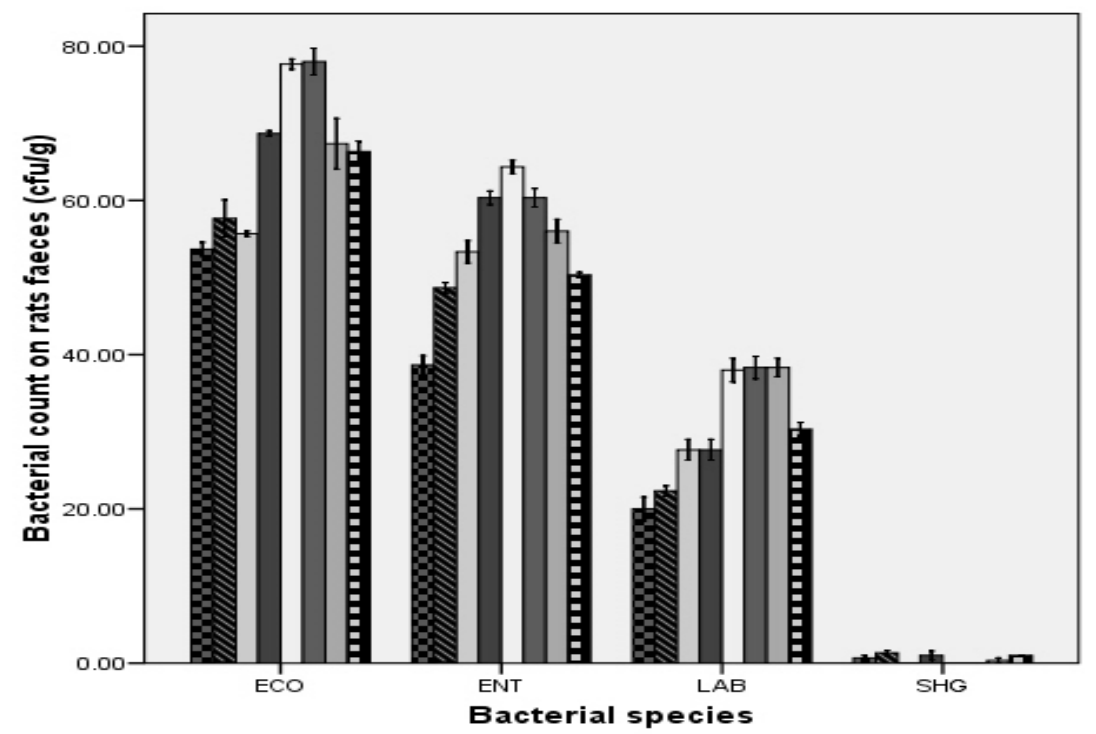

Figure 1: Bacterial count of treatment $A$ during in vivo feeding trials $\left(\times 10^{5} \mathrm{CFU} / \mathrm{mL}\right)$. $A$, rats fed with basal diet only; LAB, Lactobacillus sp.; ENT, other enterobacteria; ECO, E. coli; SHG, S. dysenteriae.
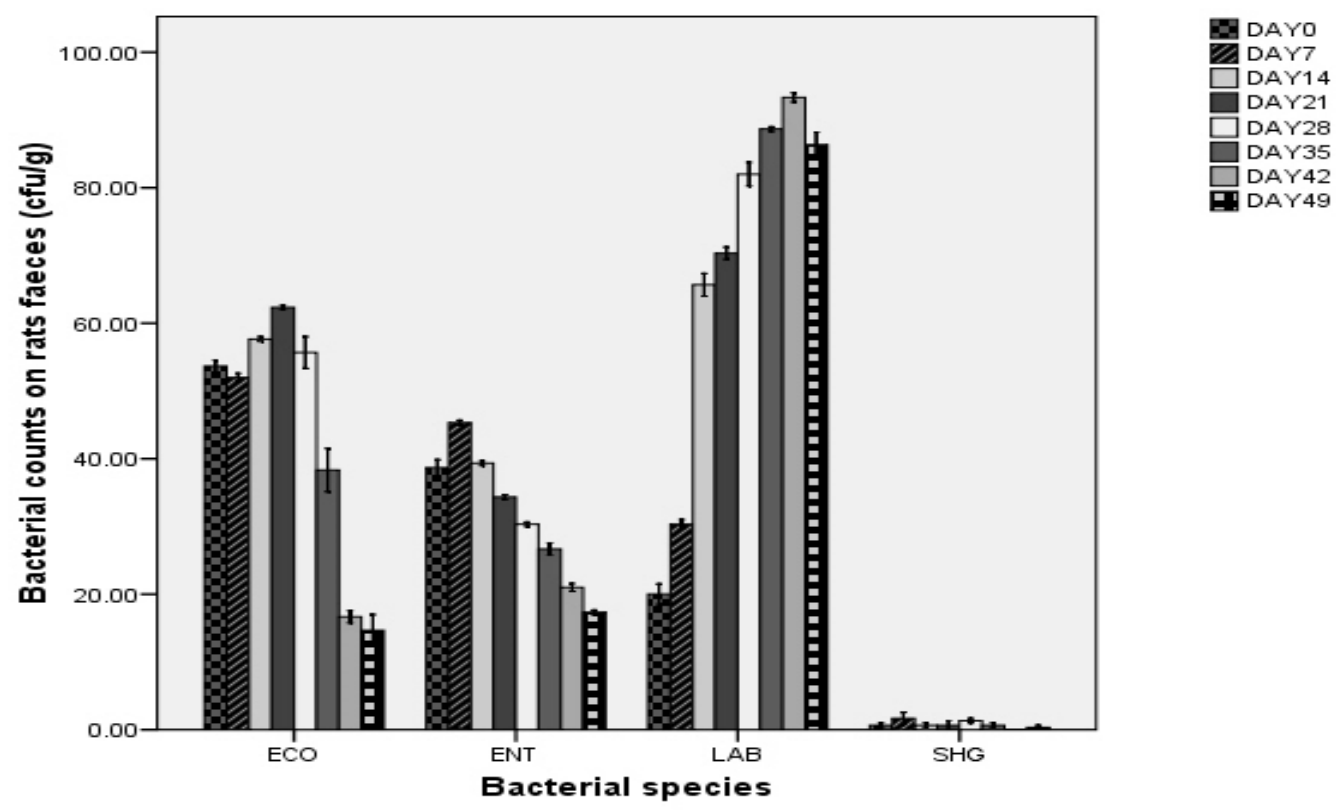

Figure 2: Bacterial count of treatment $B$ during in vivo feeding trials ( $\left.\times 10^{5} \mathrm{CFU} / \mathrm{mL}\right)$. B, rats fed with fermented mucuna beans flour only; LAB, Lactobacillus sp.; ENT, other enterobacteria; ECO, E. coli; SHG, S. dysenteriae. 

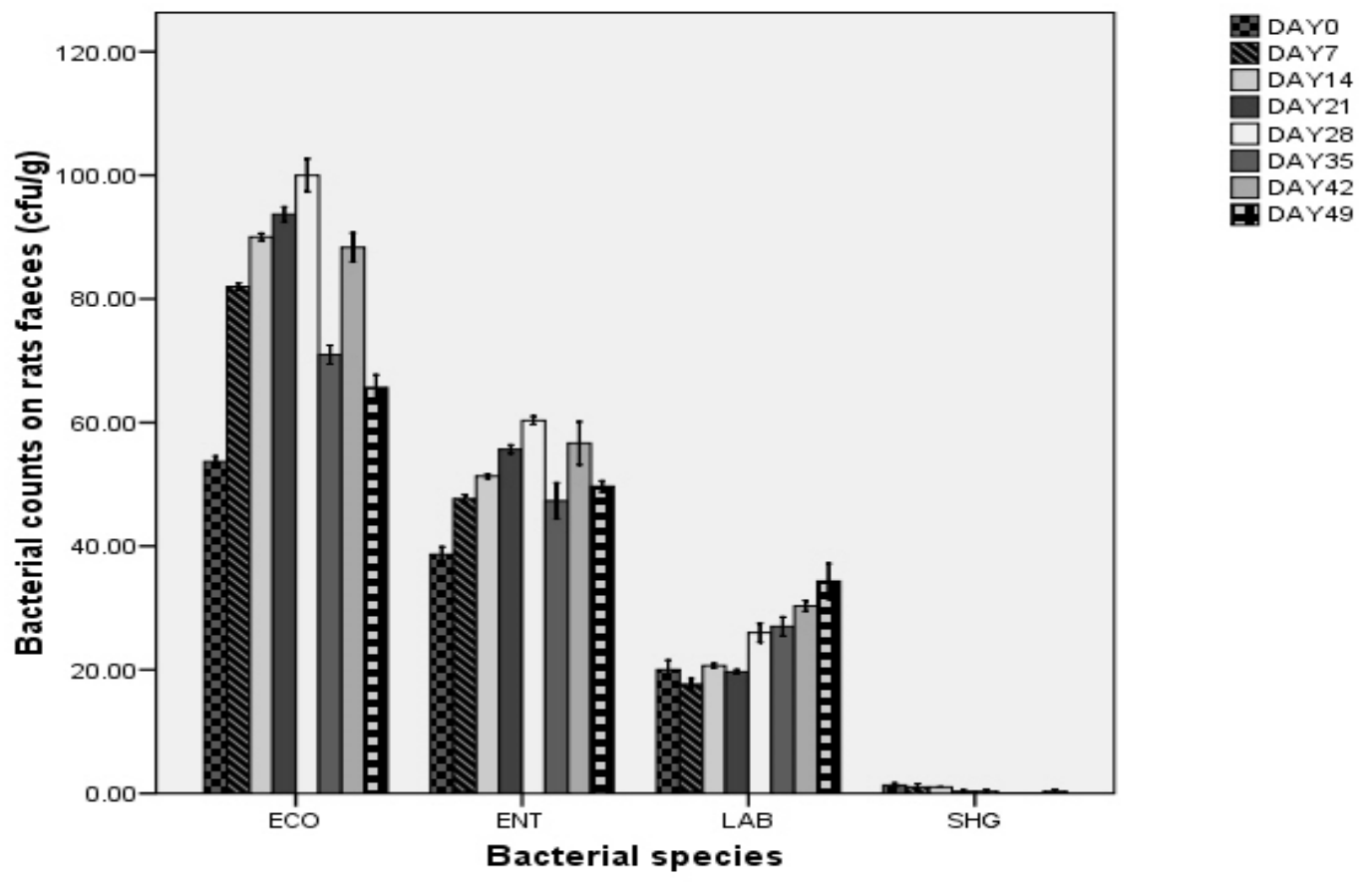

Figure 3: Bacterial count of treatment $C$ during in vivo feeding trials $\left(\times 10^{5} \mathrm{CFU} / \mathrm{mL}\right)$. C, rats infected with $E$. coli without further treatment; LAB, Lactobacillus sp.; ENT, other enterobacteria; ECO, E. coli; SHG, S. dysenteriae.
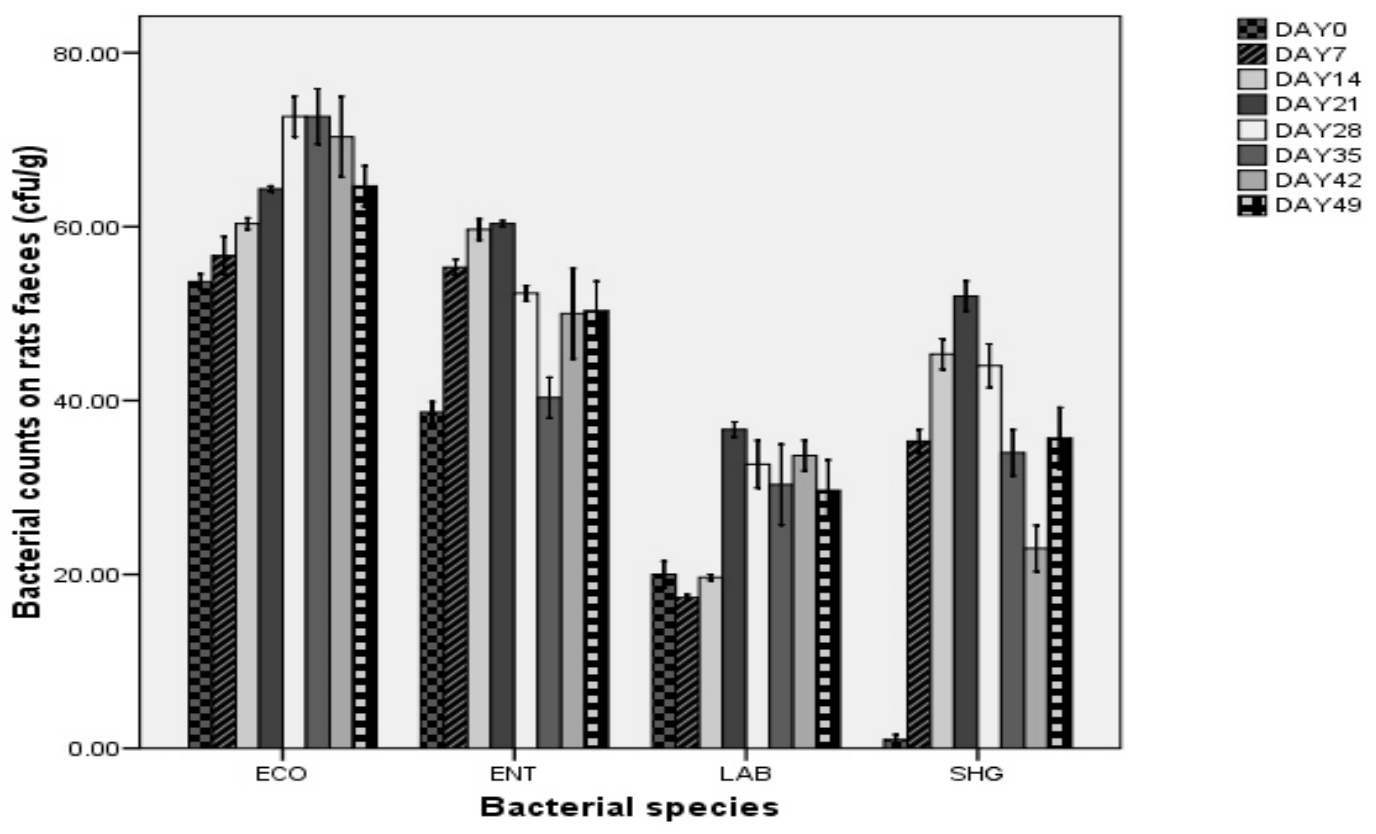

Figure 4: Bacterial count of treatment $D$ during in vivo feeding trials $\left(\times 10^{5} \mathrm{CFU} / \mathrm{mL}\right)$. $\mathrm{D}$, rats infected with $S$. dysenteriae without further treatment; LAB, Lactobacillus sp.; ENT, other enterobacteria; ECO, E. coli; SHG, S. dysenteriae. 

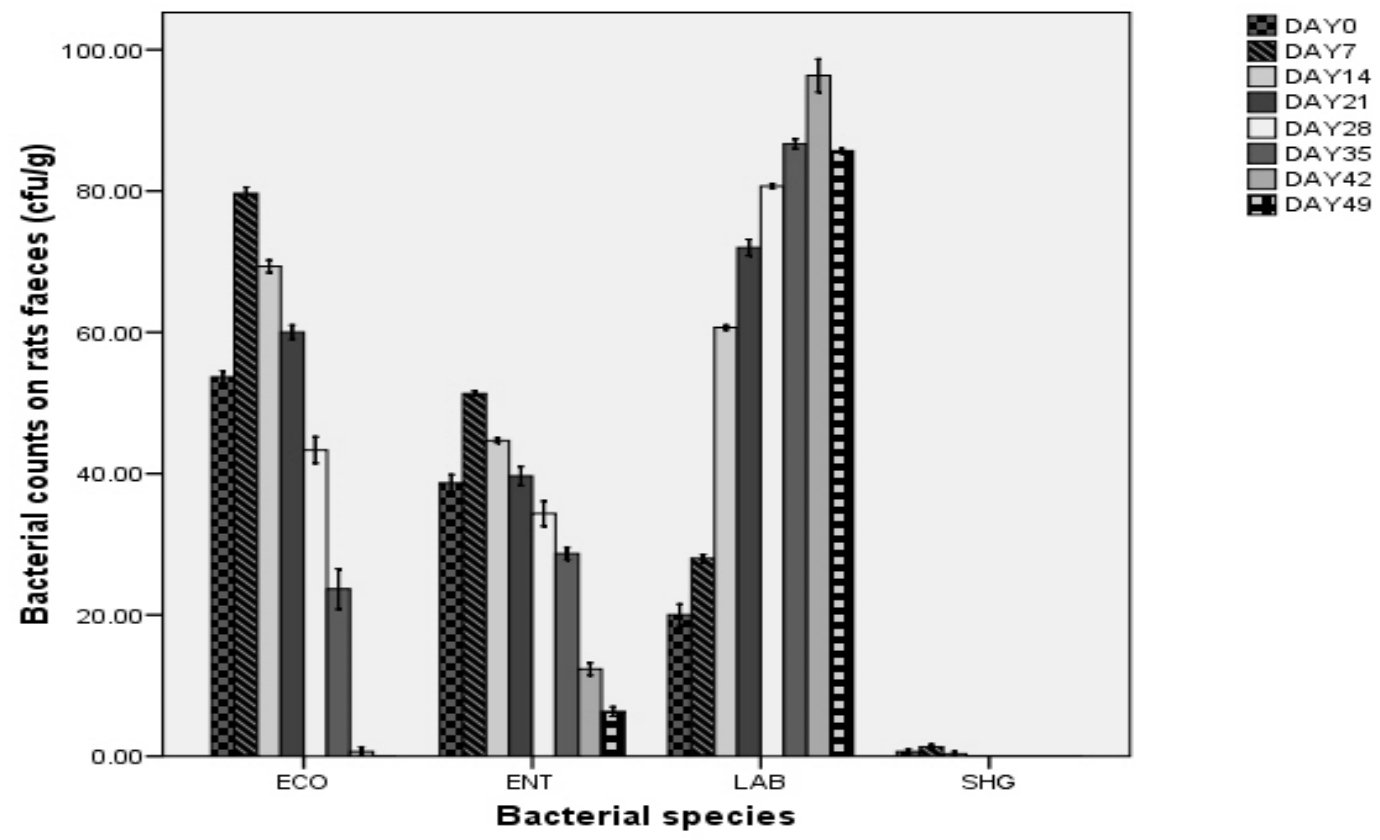

Figure 5: Bacterial count of Treatment $\mathrm{E}$ during in vivo feeding trials $\left(\times 10^{5} \mathrm{CFU} / \mathrm{mL}\right)$. $\mathrm{E}$, rats infected with $E$. coli and then fed with mucuna beans flour fermented with L. acidophilus; LAB, Lactobacillus sp.; ENT, other enterobacteria; ECO, E. coli; SHG, S. dysenteriae.
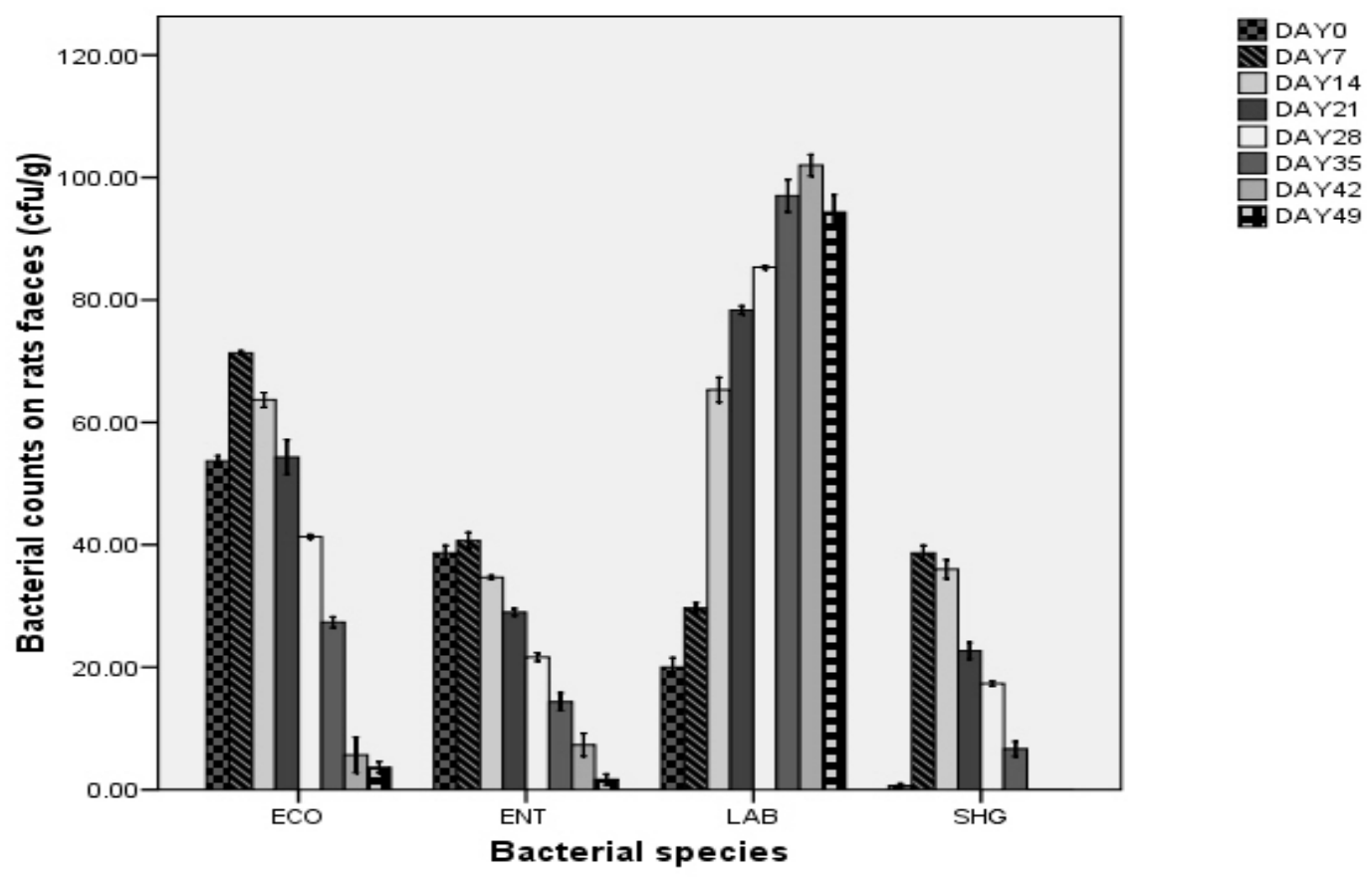

Figure 6: Bacterial count of Treatment $\mathrm{F}$ during in vivo feeding trials $\left(\times 10^{5} \mathrm{cfu} / \mathrm{mL}\right) . \mathrm{F}$, rats infected with $S$. dysenteriae and then fed with mucuna beans flour fermented with L. acidophilus; LAB, Lactobacillus sp.; ENT, other enterobacteria; ECO, E. coli; SHG, S. dysenteriae. 
The results of the effect of the fermented mucuna beans flour on the body weight of the animals compared with control is as shown in Figure 7 . There were significant differences $(p \leq 0.05)$ in the weight of animals in treatment $B$ compared to the control group (A) while there was a significant increase in the weight of the rats infected with pathogens and then fed with the fermented mucuna beans flour compared to those infected without control.
The result of the Haematological analyses of the rats blood is presented is Table 7. There was significant $(p \leq$ 0.05 ) difference between the WBC count of the group infected without further treatments $(C, D)$ compared to the other groups. Also, the RBC, Platelet, PCV and haemoglobin count of the infected group without further treatment was significantly $(p \leq 0.05)$ lower than that of the other groups. Furthermore, all the internal organs of the infected rats without further treatments $(C, D)$ were significantly $(p \leq 0.05)$ lower in weight than the other groups and then fed with mucuna beans flour fermented with $L$. acidophilus (Table 8).

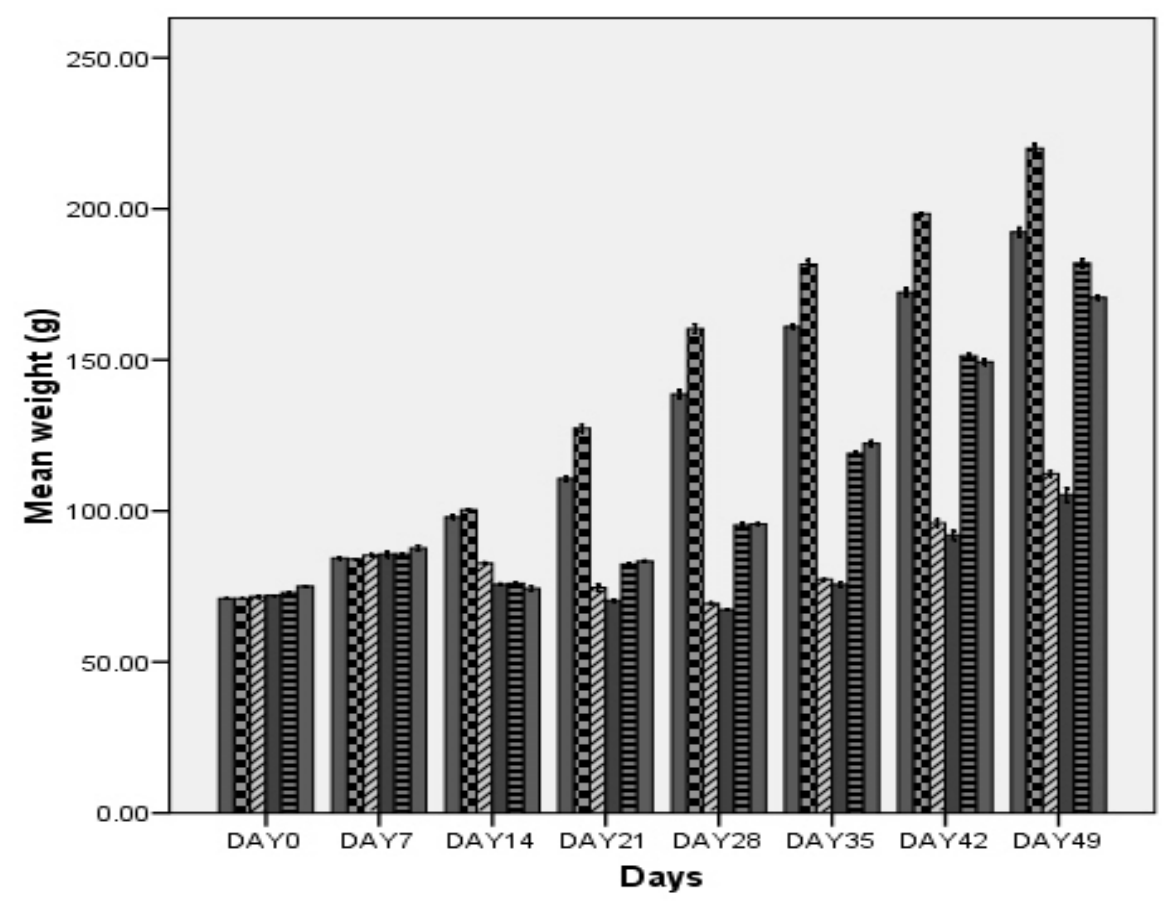

Figure 7: Effect of the fermented mucuna beans flour on the growth performance (weight in g) of rats during in vivo feeding trial. A, rats fed basal diet only; $\mathrm{B}$, rats fed with fermented mucuna flour only; $\mathrm{C}$, rats infected with $E$. coli without treatment; D, rats infected with Shigella without treatment; $\mathrm{E}$, rats infected with $E$. coli and then fed with $L$. acidophilus fermented mucuna flour; F, rats infected with Shigella and then fed with $L$. acidophilus fermented mucuna flour.

Table 7: Haematological parameter of rats fed with Mucuna pruriens beans flour fermented with L. acidophilus (values are mean \pm S.E.M).

\begin{tabular}{lccccc}
\hline Treatments & RBC $\left(10^{3} / \mu \mathrm{L}\right)$ & WBC $\left(10^{6} / \mu \mathrm{L}\right)$ & PCV $(\%)$ & Haemoglobin $(\mathrm{g} / \mathrm{dL})$ & Platelet $\left(10^{3} / \mu \mathrm{L}\right)$ \\
\hline A & $6.84 \pm 0.04^{\mathrm{b}}$ & $8.58 \pm 0.08^{\mathrm{a}}$ & $39.20 \pm 0.35^{\mathrm{b}}$ & $12.80 \pm 0.40^{\mathrm{b}}$ & $167.33 \pm 2.71^{\mathrm{b}}$ \\
B & $8.65 \pm 0.23^{\mathrm{c}}$ & $7.20 \pm 0.11^{\mathrm{a}}$ & $44.83 \pm 1.04^{\mathrm{c}}$ & $15.27 \pm 0.23^{\mathrm{c}}$ & $264.00 \pm 9.29^{\mathrm{c}}$ \\
C & $5.95 \pm 0.15^{\mathrm{a}}$ & $18.12 \pm 0.44^{\mathrm{c}}$ & $29.60 \pm 0.25^{\mathrm{a}}$ & $10.23 \pm 0.26^{\mathrm{a}}$ & $133.67 \pm 2.60^{\mathrm{a}}$ \\
D & $5.63 \pm 0.20^{\mathrm{a}}$ & $22.56 \pm 0.52^{\mathrm{c}}$ & $33.17 \pm 0.52^{\mathrm{a}}$ & $9.50 \pm 0.15^{\mathrm{a}}$ & $137.33 \pm 8.41^{\mathrm{a}}$ \\
E & $6.97 \pm 0.03^{\mathrm{b}}$ & $11.51 \pm 0.13^{\mathrm{b}}$ & $35.47 \pm 0.83^{\mathrm{b}}$ & $12.00 \pm 0.15^{\mathrm{b}}$ & $173.33 \pm 9.28^{\mathrm{b}}$ \\
F & $7.20 \pm 0.08^{\mathrm{b}}$ & $10.21 \pm 0.11^{\mathrm{b}}$ & $38.73 \pm 0.20^{\mathrm{b}}$ & $13.27 \pm 0.20^{\mathrm{b}}$ & $200.67 \pm 5.93^{\mathrm{b}}$ \\
\hline
\end{tabular}

$A$, rats fed basal diet only; $B$, rats fed with fermented mucuna flour only; C, rats infected with E.coli without treatment; $D$, rats infected with Shigella without treatment; E, rats infected with E. coli and then fed with $L$. acidophilus fermented mucuna flour; F, rats infected with Shigella and then fed with $L$. acidophilus fermented mucuna flour. Values with different superscripts in each column are significantly different. 
Table 8: Organ weight of the rats fed with Mucuna pruriens beans flour fermented with Lactobacillus acidophilus (values are mean \pm S.E.M).

\begin{tabular}{lcccc}
\hline Treatments & Heart $(\mathrm{g})$ & Liver $(\mathrm{g})$ & Kidney $(\mathrm{g})$ & Lungs $(\mathrm{g})$ \\
\hline $\mathrm{A}$ & $0.663 \pm 0.01^{\mathrm{c}}$ & $4.527 \pm 0.03^{\mathrm{c}}$ & $1.344 \pm 0.01^{\mathrm{b}}$ & $0.756 \pm 0.01$ \\
$\mathrm{~B}$ & $0.739 \pm 0.01^{\mathrm{c}}$ & $5.179 \pm 0.04^{\mathrm{c}}$ & $1.537 \pm 0.01^{\mathrm{c}}$ & $0.864 \pm 0.01$ \\
$\mathrm{C}$ & $0.387 \pm 0.00^{\mathrm{a}}$ & $2.644 \pm 0.02^{\mathrm{a}}$ & $0.785 \pm 0.01^{\mathrm{a}}$ & $0.441 \pm 0.00^{\mathrm{a}}$ \\
$\mathrm{D}$ & $0.363 \pm 0.01^{\mathrm{a}}$ & $2.479 \pm 0.06^{\mathrm{a}}$ & $0.736 \pm 0.02^{\mathrm{a}}$ & $0.414 \pm 0.01^{\mathrm{a}}$ \\
E & $0.592 \pm 0.00^{\mathrm{b}}$ & $4.042 \pm 0.02^{\mathrm{b}}$ & $1.199 \pm 0.00^{\mathrm{b}}$ & $0.673 \pm 0.00^{\mathrm{b}}$ \\
F & $0.589 \pm 0.00^{\mathrm{b}}$ & $4.017 \pm 0.02^{\mathrm{b}}$ & $1.423 \pm 0.23^{\mathrm{c}}$ & $0.677 \pm 0.00^{\mathrm{b}}$ \\
\hline
\end{tabular}

$A$, rats fed basal diet only; $B$, rats fed with fermented mucuna flour only; C, rats infected with $E$. coli without treatment; D, rats infected with Shigella without treatment; E, rats infected with $E$. coli and then fed with $L$. acidophilus fermented mucuna flour; $F$, rats infected with Shigella and then fed with $L$. acidophilus fermented mucuna flour. Values with different superscripts in each column are significantly different.

\section{DISCUSSION}

Several foods have been investigated as vehicles of probiotic organisms, such as cheese, yoghurt, soy (Bergamini et al., 2005) and lima beans (Ojokoh and Daramola, 2012). In order to exert their probiotic effects on the host, the lactic acid bacteria should be present in sufficient numbers in the vehicle as at the time of consumption (Gao et al., 2010). The number of viable probiotic organism needed to confer benefit on the host varies greatly with the food type and strain of the probiotic organism. Nevertheless, a viable count of $10^{7} \mathrm{CFU} / \mathrm{mL}$ of the bacteria has been recommended (Lee and Wong, 1998) as the minimal population of probiotics necessary to give a noticeable effect on the host health. To survive passage through the stomach and small intestine, probiotic strains must tolerate the acidic and protease-rich conditions of the stomach, and survive and grow in the presence of bile acids. Hence, acid tolerance is one of the first properties screened for when selecting probiotic strains. The profuse and moderate growth of $L$. acidophilus at $\mathrm{pH} 4$ and $\mathrm{pH} 3$ as well as moderate growth in $10 \%$ bile suggests that the organism will be able to survive the harsh condition of the stomach environment and therefore be able to exert its probiotic effects. This had been observed earlier by Ojokoh and Daramola (2012).

The fermented mucuna beans flour stored at room temperature for 14 days had a significant increase in the bacterial growth of $183.67 \times 10^{5} \mathrm{CFU} / \mathrm{mL}$ compared to the ones stored at refrigeration temperature $\left(94.67 \times 10^{5}\right.$ $\mathrm{CFU} / \mathrm{mL}$ ). The $L$. acidophilus used having a considerable increase in cell growth after storage therefore satisfied this criterion for good probiotic bacteria. However, to guarantee high survival rate of the probiotic bacteria with the sufficient stability of the vehicle, the probiotic product must be cooled during storage (Lee and Wong, 1998; Vasiljevic and Shah, 2008). This is to ensure that the vehicle remain stable, since fermentation may continue at room temperature and the organism may cause its spoilage. This is in line with earlier reports that $L$. acidophilus stored at $4{ }^{\circ} \mathrm{C}$ in normal refrigerator guarantees complete stability of the organism for 24 months while storage at room temperature usually decrease the stability time to 4 weeks (Rerksuppaphol and Rerksuppaphol, 2010.)

The count of $94.67 \times 10^{5} \mathrm{CFU} / \mathrm{mL}$ of $\mathrm{LAB}$ in the product stored at refrigeration temperature showed that the fermented mucuna beans flour can be cooled without affecting the survival of the probiotic bacteria therefore it is a good vehicle for probiotic bacteria. The increase in the acidity of the fermented mucuna products as shown by the reduction in the $\mathrm{pH}$ observed in this investigation may be due to the production of acid by the organisms, this has been observed earlier by Dziedzoaze et al. (1996).

The reduction in the carbohydrate content of the mucuna beans flour after fermentation may be due to the fact that the Lactobacilli use them up as source of energy for their growth and this is in consonance with earlier reports (Odetokun, 2000; Aderiye and Laleye, 2003) that fermentation process reduces carbohydrate contents of cereal and legume blends. Also the significant increase in the protein content of the products may be due to the increase in cellular mass during fermentation. This has been reported earlier by other researchers during fermentation of different types of food (Mosha and Vicent, 2004; Ojokoh and Wei, 2011). The decrease in the ash content in the fermented mucuna beans flour might be due to the leakage of some of the water soluble inorganic matter into the medium used for the fermentation (Antai and Nzeribe, 1992). The reduction in the fibre content of the fermented mucuna beans flour is desirable because of the attendant drawbacks of high fibre content in foods especially during weaning which include reduced digestibility, irritation of gut mucosa, reduced minerals and vitamin availability (Odetokun, 2000). The high moisture content of the fermented product is a precursor to its perishability, since most spoilage bacteria survive well at high moisture level. The application of probiotics as growth enhancer and in prevention intestinal disorders as well as disease control has been in existence from early periods (Fuller, 1989; de Vrese and Marteau, 2007). Probiotics are now used as replacement for the widely used antibiotics and synthetic chemical feed supplements. This is because, of their ability to inhibit the growth of pathogenic organisms and also by enhancing absorption of nutrients (Ojokoh and Daramola, 2012). 
After the 49 days of trial feeding, it was observed that rats infected with $E$. coli $(\mathrm{E})$ and $S$. dysenteriae $(\mathrm{F})$ and then fed experimental diet were found to weigh more than the ones infected and not given the experimental diet (C, D) the rapid increase in weight of animals fed with fermented mucuna flour may be due to its high protein content $(37.36 \%)$. Protein is used majorly for cell repair and body building. This is in agreement with earlier report on studies of weight training which showed significant gains in muscles of people taking a very high protein diet when compared with those who had moderate intake (Tipton and Wolfe, 2004). Also, rats infected with the pathogens without giving them experimental diet showed the symptoms of wet-loose faeces and weakness (C) and bloody diarrhea (D) throughout the experimental period whereas in the groups infected with pathogen then fed experimental diet showed those symptoms only during the first 21 days (E) and 17 days (F) of infection which disappeared rapidly after they were given the probiotic food. There were no symptoms of diarrhea in the rats fed the basal diet and those fed the experimental diet alone throughout the experiment period. This is in line with the previous report of Isolauri et al. (1991) who reported the use of some probiotic Lactobacillus strains in the dairy industry to reduce the incidence of traveller's diarrhea and to promote recovery from acute diarrhea.

The lower number of $E$. coli and Shigella as well as other Enterobacteriaceae observed in this study from the microbial analyses of the faecal samples of the rats showed that their growth might have been inhibited by the presence of the Lactobacillus species. Also, they may have actually been killed by secretions from the Lactobacillus species as some of them have been reported to be capable of producing biocidal substances. This is in agreement with the work of Bukowska et al. (1998) that $L$. plantarum increases the levels of $\alpha-3$ unsaturated fatty acids in foods thus protecting such foods from multiplication of harmful bacteria.

Haematopoeitic system is one of the most important index of physiological and pathological status in man and animals (Adeneye et al., 2006). The haematological parameters of all the groups infected with the pathogens and then fed the experimental diets as well as those fed with basal diet, and those fed only experimental diet falls within the laboratory permissible limits compared to the groups infected with the pathogens and not fed the experimental diet which is far outside the permissible limits. This shows that the mucuna beans flour fermented with Lactobacillus species helps in quick recovery from infections caused by these organisms.

In all, the groups infected with $E$. coli and then fed with the mucuna beans flour fermented with $L$. acidophilus showed a better recovery than the groups infected with Shigella and then fed with mucuna beans flour fermented with $L$. acidophilus, this could be because the group infected with Shigella lost blood during infection. All the animals infected with the pathogens and then fed with the mucuna beans fermented with L. acidophilus recovered fully as shown by their weight as well as their haematological parameters. This may be due to the reported ability of $L$. acidophilus to produce Vitamin $\mathrm{K}$, lactase, bacteriocins such as acidolin, acidophilin and lactocidin (Isolauri et al., 1991). However, more research is needed to shed more light on this.

\section{CONCLUSION}

From the foregoing, there is great amount of evidence suggesting that $L$. acidophilus showed good growth and survival in mucuna beans flour. Furthermore, it had positive effect on the intestinal flora balance of the rats as well as enhancing their growth as revealed in their body weight gain and haematological parameters. Therefore, mucuna beans flour fermented with Lactobacillus acidophilus could be used as an excellent probiotic food.

\section{Acknowledgement}

There is no official ethic codes for the use of animals for research purposes in Nigeria.

\section{REFERENCES}

Adeneye, A. A., Ajagbonna, O. P., Adeleke, T. I. and Bello,S. O. (2006). Preliminary toxicity and phytochemical studies of the stem bark aqueous extract of Musanga cecropioides in rats. Journal of Ethnopharmacology 105, 374-379.

Aderiye, B. I. and Laleye, S. A. (2003). Relevance of fermented food products in southwest Nigeria. Plant Foods for Human Nutrition (Formerly Qualitas Plantarum) 3, 1-16.

Ani, A. O. and Adiegwu, L. U. (2005). The feeding value of velvet beans (Mucuna pruriens) to weaner rabbits. In: Proceeding of the 30th Annual Conference of Nigerian Society for Animal Production. University of Nigeria, Nsukka, Nigeria. pp. 186-189.

Antai, S. P. and Nzeribe, E. (1992). Suitability of using sieved or unsieved maize mash for production of ogi a fermented cereal food. Plant Foods and Human Nutrition 42, 25-30.

Association of Official Analytical Chemists (1995). Official methods of analysis. $14^{\text {th }}$ Edn. Washington D. C.

Bergamini, C. V., Hynes, E. R., Quiberoni, A. and Zalazar, C. V. (2005). Probiotic bacteria as adjunct starters: influence of the addition methodology on their survival in a semi-hard Argentinean cheese. International of Food Resources 38, 597-604.

Bukowska, H., Pieczul-Mroz, J., Jastrzebska, M., Chelstowski, K. and Naruszewicz, M. (1998). Decrease in fibrinogen and LDL-cholesterol levels upon supplementation of diet with $L$. plantarum in subjects with moderately elevated cholesterol. Atherosclerosis 137, 437-438.

de Vrese, M. and Marteau, P. R. (2007). Probiotics and prebiotics: Effects on diarrhea. Journal of Nutrition 137, 803-811.

Dziedzoaze, T. N., Ellis, W. O. and Oldham, J. A. (1996). Effect of cassava varietal differences and 
fermentation time on the quality of a gbelina. In: Traditional Fermented Food Processing in Africa. Halm, M. and Jakobsen, M. (eds.). Proceedings of the Third Biennial Seminar on African Fermented Food, FRI, DANIDA, KVL, Accra Ghana. pp. 17-25.

Ferriera, H. A., Peria, B. K., Gernat, A. G., Carew, L. B. and Matamoros, I. A. (2003). Evaluation of different processing methods of velvet bean (Mucuna pruriens) for use as a feed ingredient for broilers. Journal of Tropical and Subtropical Agroecosystems 1, 277-286.

Fuller, R. (1989). Probiotics in man and animals. Revolution Journal of Applied Bacteriology 90, 343352.

Gao, X. W., Mubasher, M., Fang, C. Y., Reifer, C. and Miller, L. E. (2010). Dose-response efficacy of a proprietary probiotic formula of Lactobacillus acidophilus CL1285 and Lactobacillus casei LBC80R for antibiotic-associated diarrhea and Clostridium difficile-associated diarrhea prophylaxis in adult patients. American Journal of Gastroenterology 105, 1636-1641.

Gilbert, R. (2002). Mucuna pruriens in Malawi. A promising legume with a troubled history. In: Food and Feed from Mucuna: Current Uses and the Way Forward. Flores, M. B., Marjatta, E., Myhrman, R., Lyndon, B. and Carsky, R. J. (eds.). Proceedings of an international workshop. CIDICCO, CIEPCA and World Hunger Research Center. Tegucigalpa, Honduras. pp. 48-57.

Guarner, F. and Scaafsma, G. J. (1998). Probiotics. International Journal of Food Microbiology 39, 237238.

Isolauri, E., Juntunen, M., Rautanen, T., Sillanaukee, P. and Koivula, T. (1991). A human Lactobacillus strain (Lactobacillus casei sp. strain GG) promotes recovery from acute diarrhoea in children. Pediatrics 88, 90-97.

Janardhanan, K., Gurumoorthi, P. and Pugalenthi, M. (2003). Nutritional potential of five accessions of a South Indian tribal pulse, Mucuna pruriens var. utilis I. The effect of processing methods on the content of $L$ DOPA, phytic acid and oligosaccharides. Journal of Tropical and Subtropical Agroecosystems 1, 141-152.

Lee, Y. K. and Wong, S. F. (1998). Stability of lactic acid bacteria in fermented milk. In: Lactic Acid Bacteria, Microbiology and Functional Aspects. Salminen, S. and von Wright, A. (eds.). Marcel Dekker Inc. New York. pp. 103-114.

Lilly, D. M. and Stillwell, H. (1965). Probiotics: Growthpromoting factors produced by microorganisms. Science 147, 747-748.

Mosha, T. C. E. and Vicent, M. M. (2004). Nutritional value and acceptability of homemade maize/sorghumbased weaning mixtures supplemented with rojo bean flour, ground sardines and peanut paste. International Journal of Food Sciences and Nutrition 55, 301-315.

Odetokun, S. M. (2000). Effect of fermentation on some physiochemical properties, antinutrients and in vitromultienzyme digestibility of selected legumes. Ph.D
Thesis, Federal University of Technology, Akure, Nigeria. pp. 102-135.

Ojokoh, A. O. and Daramola, M. D. (2012). Evaluation of lima bean flour fermented with Lactobacillus $\mathrm{sp}$. as a probiotic food. African Journal of Food Science 6, 352361.

Ojokoh, A. O. and Wei, Y. (2011). Effect of fermentation on chemical composition and nutritional quality of extrude and fermented soya products. International Journal of Food Engineering 7, 4-6.

Rerksuppaphol, S. and Rerksuppaphol, L. (2010). Lactobacillus acidophilus and Bifidobacterium bifidum stored at ambient temperatures are effective in the treatment of acute diarrhea. Annals of Tropical Paediatrics 30(4), 299-304.

Sanders, M. E. (2003). Probiotics: Considerations for human health. Nutrition Revolution 61, 91-99.

Sperti, G. S. (1971). Probiotics. West Point, CT: AVI Publishing Co. New York. pp. 278-312.

Tipton, K. D. and Wolfe, R. R. (2004). Protein and amino acids for athletes. Journal of Sports Science. 22(1), 65-79.

Vasiljevic, T. and Shah, N. P. (2008). Probiotics. From Metchnikoff to bioactives. International Journal of Dairy 18, 714-728. 